\title{
FAMILY AND DYSFUNCTION IN CONTEMPORARY IRISH NARRATIVE AND FILM
}

Marisol Morales-Ladrón, ed.

Oxford, Bern, Berlin, Brussels, Frankfurt, New York and Vienna: Peter Lang, 2016.

(by María Isabel Seguro Gómez. Universitat de Barcelona)

isabelseguro@ub.edu

Family and Dysfunction in Contemporary Irish Narrative and Film explores how the family in Irish culture has functioned, and continues functioning, as an essential icon of Irishness by analysing a selection of key literary and filmic texts of the last four decades. Interestingly, the rapid and drastic changes that the family has undergone, especially as the result of the Celtic Tiger years, do not necessarily entail that the institution has lost importance -quite the opposite, and this is reflected in the artistic output of the nation overall.

As Robert G. Lee points out, the importance of exploring the evolution of the family -as a metaphor and cultural reflection of a nation- is intrinsically linked to the fact that it is "the primary ideological apparatus, the central system of symbols, through which the state contains and manages contradictions in the social structure" (7). That is, individuals are primarily socialised by the family -the basic unity by which one becomes a member of a community. Consequently, the state's intervention by regulating marriage, parenting, or adoption, for example, is a means of formulating identity and one's membership within a given community according to certain discourses.

The contributors, therefore, particularly underline the representation of the Irish family as having oscillated between "idealization and denouncement" (2), often giving place to dysfunctional family portrayals. The contributors also emphasise 


\section{Reviews}

that the image/ideal of the family is further undermined by the strict regulation in matters affecting marriage and hence the family, as a result of the 1937 Constitution to the Marriage Bar, legislation on divorce or contraception, which gave rise to what has been qualified as "the heterosexual and patriarchal caged family" (6-7). The constraining effects of such regulation made of the family a dysfunctional entity as reflected in Ireland's literary and cinematic output throughout the $20^{\text {th }}$ century to the present. In fact, a number of scholars, such as Rebecca Wilson, have emphasised that the deconstruction of the idealised -even mythologised- Irish family "promulgated in a rustic utopia by Eamon de Valera" (40) lies behind much cultural output, especially since the 1990s.

Despite the importance and the omni-presence of families in Irish culture, the volume's significance is its focus on how changes brought by the Celtic Tiger have had their effects on the family, since such studies have not proliferated. Among the few exceptions is the edited volume by Yovenne O'Keeffe and Claudia Reese Voices, Inherited Lives: Literary and Cultural Representations of the Irish Family (7).

Family and Dysfunction in Contemporary Irish Narrative and Film opens with Marisol Morales-Ladrón's chapter "Portraits of Dysfunction in Contemporary Irish Women's Narratives: Confined to the Cell, Lost to Memory". As the title indicates, the author focuses on how dysfunctional families have been portrayed in texts written by women from the 1980s to the present. Morales-Ladrón highlights the importance of Irish women writing, bearing in mind how they were confined not only by the national imagery within the family as mothers and wives, but also by law. Women's writing, thus, is particularly important for dismantling the official discourse(s) on the family and consequently on the nation and notions of Irishness. This is particularly achieved by stories based on traumatic experiences within the family. MoralesLadrón draws attention to the number of texts with absent and/or violent fathers and silenced, abjected mothers. In this way, the author highlights how the demystification of the nuclear Catholic family has been a constant in Irish letters.

The next chapter, "Home Revisited: Family (Re)Construction in Contemporary Irish Autobiographical Writing" by Inés Praga, opens with an introduction on life writing, memoir and autobiographical novels -offering an analysis of their characteristics and how to differentiate them. Praga also explores the relationship of these genres with memory, providing thus the necessary theoretical background for a better understanding of the texts discussed. In this chapter, Praga highlights that in recent years there has been a growing number of texts reconstructing part of an author's family life -mostly during their childhood in the mid-twentieth century- that is, during the hard core de Valera years. As in the volume's first chapter, a wide range of texts has been selected from what Praga defines as (semi) autographical novels, from Patrick McCabe's The Butcher Boy (1992) to Hugo 


\section{Reviews}

Hamilton's Every Single Minute (2014). Praga's contribution revolves around the issue of remembrance and its importance in the reconstruction of certain patterns -including those of family (dys)functionality. The texts chosen highlight how the traditional family model, even in the de Valera years, was actually transgressed as seen in the portrayal of absent fathers and even absent mothers, incapable of fulfilling the roles assigned by mainstream family discourse. The aim, obviously, is to deconstruct the official grand narrative of the Irish family as an Arcadia -as well as that of the nation when reconstructed through nostalgic memory by the diaspora.

The third chapter, "Family and Dysfunction in Ireland Represented in Fiction Through the Multicultural and Intercultural Prism", by Asier Altuna-García de Salazar, is one of the most extensive in the volume. As the title points out, the chapter focuses on the recent phenomenon of immigration to Ireland and how newcomers, with their own traditions and cultural mores, inevitably challenge notions of Irishness, offering new perspectives on family dysfunctions as a result of their interaction with and penetration in 'native' Irish families. This issue is intrinsically linked to that of globalisation, the commodification of Irish culture and its effects upon identity politics. As with all the chapters in the volume, the author offers an insightful theoretical framework from which to provide a critique of the family from multicultural and transcultural perspectives. One of its assets is that it includes texts from the 1980s, before the Celtic Tiger years, as well as nonIrish authors who offer a first-hand view on immigration and its effects not only upon themselves but also on Irish society at large.

Despite the fact that immigration to Ireland is a relatively new phenomenon, the chapter explores a wide range of texts and provides an overwhelming amount of information, from short stories by established writers such as Roddy Doyle and Colm Tóibin, to the successful novel Paddy Indian (2001), by the immigrant writer Cauvery Madhavan. It also includes a section on the significance of the 2004 Citizenship Referendum and how this has been alluded to in fiction, particularly in Emer Martin's novel Baby Zero (2007).

Altuna-García offers an insightful transcultural analysis of Emer Martin's short story "The Pooka at Five Happiness" (1999) and Margaret McCarthy's My Eyes Only Look Out (2001), a collection of biographical texts about Irish of mixed race origin. These texts "advocate the need to negotiate, imagine and accept new (re) configurations of the institution of the Irish family and its members that have to comply with new discourses. Only then can the Irish nation, and even the State, be regarded as global" (193).

The following chapter, "Familiar Dysfunctionalities in Contemporary Irish Satirical Literature", authored by Juan F. Elices, draws from the strong tradition of satire 


\section{Reviews}

in Irish literature -focusing on how satire is used in certain contemporary texts to reflect upon dysfunctionality in the family which, in turn, reflects that of mainstream discourses on the nation and identity. In these texts, as Elices points out, satire is used "to offer more critical and biting views through the construction of very peculiar familiar realms" (202). Elices firstly offers a theoretical-critical introduction on satire, underlining that, despite being a slippery term, its main objective is "to display the most despicable aspects of the objects [it] aim[s] at criticizing" (204205 ), in this case, that of the conventional representation of the Irish, nuclear, patriarchal, Catholic family. For this reason Elices highlights the difficulty of finding texts that directly satirise the family due to the fact that the objects of satire are usually issues of a socio-political nature. Nonetheless the chosen texts, Anne Harverty's One Day as a Tiger (1998), Mark Macauley's The House of Slamming Doors (2010) and Justin Quinn's Merrion (2013), by providing satirical representations of dysfunctional families, criticise the excesses of the Celtic Tiger period.

Finally, Rosa González-Casademont's contribution, "Representation of Family Tropes and Discourses in Contemporary Irish-Themed Cinema" explores family tropes in Irish and Irish-themed films (films with an Irish theme and setting though produced with foreign investment) from the 1980s to the 2010s. The opening of the chapter offers a thorough overview of the characteristics of the Irish film industry and how these inevitably influence both the ideological and thematic paradigms of its production. The general trend is that mainstream film -due to the influence and processes of globalisation whereby the local characteristics are stereotyped or even effaced so that they may be identified as either "typically Irish" or universal, usually do not offer critical approaches on issues revolving around family dysfunction. Critical engagement is more frequently found in lowbudget films with very limited distribution. From this perspective, GonzálezCasademont's analysis of Margaret Cokery's 2009 film Eamon, dealing with young, incompetent parenting, provides stimulating insights. Nonetheless, González-Casademont also offers insightful readings of filmic productions by well-known Irish filmmakers such as Jim Sheridan, or of Celtic Tiger comedies, which pinpoint socio-economic changes which, in turn, affect family relations as well as the concept of the family itself.

The volume closes with three interviews, one with writer Emer Martin, conducted by Altuna-García de Salzar, and the last two with filmmakers Jim Sheridan and his daughter, Kirsten Sheridan, conducted by González-Casademont. These interviews offer first-hand impressions on how family dysfunctionality feature in Irish contemporary literature and film, complementing thus the readings of these artists' works explored in the volume. 


\section{Reviews}

All in all, Family and Dysfunction in Contemporary Irish Narrative and Film provides a thorough overview of how the family -as an institution and metaphor for the Irish Republic and Irishness- has more often than not been portrayed as dysfunctional -thus revealing how, in fact, the discourse sustaining the ideal Irish family as a construct was a constraining force and therefore contested, at least artistically, in various ways. Due to the scope of the literary and filmic texts explored, the volume offers an overwhelming amount of information on the narrative and films produced in the last four decades. From this perspective, it could even be considered as a critical anthology of the literary and filmic production in Ireland from the 1980s to the present.

\section{Works Cited}

LeE, Robert G. 1999. Orientals: Asian Americans in Popular Culture. Philadelphia: Temple U.P.

O'Keefe, Yvonne and Claudia Reese. (eds.) 2013. Voices, Inherited Lines: Literary and Cultural Representations of the Irish Family. Oxford: Peter Lang.
WILSON, Rebecca. 2006. "Macabre Merriment in McDonagh's Melodrama:The Beauty Queen of Leenane". In Chambers, Lilian and Eamonn Jordan (eds.) The Theatre of Martin McDonagh: A World of Savage Stories. Dublin: Carysfort Press: 27-41. 